\title{
PENGEMBANGAN STRATEGI PEMBELAJARAN (INDUKTIF Vs DEDUKTIF) DAN SELF-EFFICACY YANG SESUAI DENGAN PERKEMBANGAN PENGETAHUAN SISWA TENTANG KONSEP DASAR MATEMATIKA DI SD SE-KOTA KENDARI SULAWESI TENGGARA
}

\author{
Muhammad Yasin ${ }^{1}$, Darnawati ${ }^{2}$, Harlin Yusuf ${ }^{3}$, Iman Ashari ${ }^{4}$, Muhammad Mancipto \\ Hamid $^{5}$ \\ ${ }^{1}$ Dosen Fakultas Keguruan dan Ilmu Pendidikan Universitas Halu Oleo
}

Email : Muhammad.yasinunhalu@gmail.com

\begin{abstract}
ABSTRAK; Penelitian ini betujuan untuk mengukur efektivitas penerapan strategi pembelajaran (induktif vs deduktif) dan self-efficacy siswa tentang pengetahuan konsep dasar matematika. Dengan instrument tersebut akan diperoleh informasi makro mengenai perkembangan kemampuan siswa dalam mempelajari konsep dasar matematika di SD baik untuk kelompok siswa kelas rendah, maupun kelompok siswa kelas tinggi dengan mengembangkan strategi pembelajaran yang efektif dalam meningkatkan pengetahuan siswa tentang konsep dasar matematika. Hasil penelitian menujukkan bahwa terdapat pengaruh interaksi strategi pembelajaran (A) dan self-efficacy (B) terhadap pengetahuan siswa tentang konsep dasar matematika dengan nilai rerata kelas induktif sebaser 78.66 sedangkan rerata kelas deduktif sebesar 76,77 disamping itu juga terdapat pengaruh strategi pembelajaran induktif dan strategi pembelajaran deduktif terhadap perbedaan pengetahuan siswa tentang konsep dasar matematika baik kelompok siswa yang memiliki self efficacy tinggi maupun kelompok siswa yang memiliki self efficacy rendah.
\end{abstract}

Kata Kunci: Pengembangan Kemampuan Siswa, Strategi Pembelajaran, Self-Efficacy.

\section{PENDAHULUAN}

Proses pembelajaran matematika dasar ditingkat pendidikan dasar banyak membutuhkan alat bantu sebagai media pembelajaran. Van De Walle, (2008: 31) menyatakan sebagai guru matematika, kemampuan menggunakan benda-benda fisik atau manipulatif untuk memodelkan konsep-konsep matematika meru pakan strategi yang baik dan penting untuk membantu siswa mempelajari matematika. Sementara Asep (2008: 152,157) menyatakan bahwa matematika adalah pola berpikir, pola mengorganisasikan pembuktian yang logik; matematika adalah bahasa yang menggunakan istilah untuk mendefinisikan dengan cermat, jelas, akurat dengan simbol yang padat.Untuk penyajian materi matematika dibutuhkan strategi pembelajaran yang tepat dan efektif agar memudahkan siswa memahaminya.

Strategi pembelajaran merupakan siasat atau taktik dalam upaya meningkatkan pengetahuan siswa tentang materi pelajaran konsep dasar matematika. Jika strategi yang diterapkan guru kurang tepat maka siswa tidak tertarik belajar matematika, bahkan siswa yang pengetahuan dasarnya lemah semakin 
merasakan bahwa belajaran matematika sulit, dan semakin rendah kepercayaan dirinya (self-efficacy) yang pada akhirnya siswa malas belajar matematika akibatnya hasil belajarnya rendah. Oleh karena itu bagi siswa SD pengusaan pengetahuan konsep dasar matematika sejak dini harus kokoh dan memadai, sehingga guru merasa penting memperhatikan penggunaan strategi yang tepat, untuk menanamkan konsep dasar dan menumbuhkan kepercayaan diri dan menumbuhkan minat belajar siswa sehingga strategi pembelajaran matematika yang efektif dapat dimanfaatkan untuk membentuk kreativitas berpikir, kritis, logis, tepat dan cermat. Sehingga pelajaran matematika di SD perlu mendapat perhatian yang sungguh-sungguh tanpa mengaibaikan pelajaran lain.

Strategi pembelajaran induktif dan deduktif yang mengacu pada pembelajaran konstrutivis pada tingkat sekolah dasar merupakan suatu inovasi pengajaran dalam mencapai tujuan pengajaran yang berakar pada kompetensi dasar berpikir dan meningkatkan keterampilan serta membentuk sikap ilmiah dan berpikir kreatif, baik produk maupun proses. Namun efektivitas dan sasaran serta tujuan yang diharapkan dari strategi pembelajaran tentang konsep dasar matematika tersebut masih jauh dari harapan. Berdasarkan hasil pengamatan guru-guru SD, bahwa rendahnya pemahaman siswa pada konsep dasar matematika bukan disebabkan sukarnya materi pelajaran, tetapi beberapa diantara siswa kurang berminat dan siswa sudah takut duluan sebelum belajar diberikan atau beranggapan bahwa pelajaran matematika sulit, sehingga bersikap kurang percaya diri, padahal kepercayaan diri atau self-efficacy berhubungan dengan keyakinan pribadi bahwa jika belajar dengan keyakinan akan kemampuan untuk menyelesaikan suatu tugas dengan sukses maka hasil belajar mendapat prestasi baik.

Belajar dengan menggunakan strategi induktif atau deduktif kepada siswa diharakan kemampuan berpikir secara mandiri akan memberikan dampak yang baik bagi perkembangan kemampuan bernalar sehingga konsep-konsep dasar matematika mudah dipahami siswa.

Jadi untuk penyajian materi pelajaran konsep dasar matematika dibutuhkan strategi pembelajaran yang memungkinkan dapat meningkatkan pengetahuan siswa. Salah satu strategi pembelajaran potensial yang masih jarang digunakan guru dalam proses pembelajaran adalah strategi pembelajaran induktif. Dalam penelitian eksperimen ini dipilih sebagai variabel perlakuan strategi pembelajaran induktif diperlukan pada kelas eksperimen dan strategi pembelajaran deduktif diperlukan pada kelas control. Kemudian variabel 
atribut dipilih self-efficacy yang masih jarang menjadi perhatian guru, dan sebagai

\section{METODE PENELITIAN}

\section{Jenis dan Lokasi Penelitian}

Penelitian ini digolongkan sebagai penelitian deskriptif yang bersifat regresi dan lokasi penelitian ini dilaksanakan pada siswa SD Negeri Kota Kendari.

\section{Variabel Penelitian}

Variable yang digunakan dalam penelitian ini adalah sebagai berikut:

1. Variabel penelitian terdiri atas variabel pengaruh.Variabel pengaruh yang diselidiki melalui studi eksperimen atau variabel bebas perlakuan adalah strategi

\section{HASIL DAN PEMBAHASAN}

Tujuan dari penelitian ini adalah untuk menganalisis dan mengkaji secara komprehensif konsep dasar matematika dengan strategi pembelajaran induktif dan strategi pembelajaran deduktif matematik siswa ditinjau dari self-efficacy. Selain itu, dianalisis pula pembelajaran terhadap penggunaan strategi pembelajaran induktif dari strategi pembelajaran deduktif. Data dalam penelitian ini terdiri atas data kualitatif dan data kuantitatif. Data kualitatif diperoleh dari hasil observasi di Sekolah. Sedangkan data kuantitatif diperoleh dari hasil tes strategi pembelajaran induktif dan deduktif, serta skala self-efficacy pada sekolah yang diteliti. Pada awalnya, sebelum peneliti melakukan pemberian tes berupa strategi variabel terikat pengetahuan siswa tentang konsep dasar matematika.

pembelajaran (Induktif versus deduktif), dan variabel atribut self efficacy dengan variabel terikat pengetahuan siswa tentang konsep dasar matematika

2. Variabel kriterion yang diukur sebagai indikator keberhasilan adalah tingkat pengetahuan siswa tentang konsep dasar matematika.

pembelajaran induktif dan tes strategi pembelajaran deduktif, terlebih dahulu dilakukan observasi tentang pengetahuan dasar matematika dan diberi angket selfefficacy. Hasilnya dianalisis dan dilaporkan dalam laporan hasil penelitian ini.

Data dari dua kelas sampel penelitian dianalisis secara deskriptif dan inferensial untuk menjawab permasalahan penelitian ini. Pada analisis deskriptif dikemukakan nilai yang diperoleh siswa dari hasil tes strategi pembelajaran induktif dan deduktif serta angket self-efficacy. Sedangkan pada analisis inferensial dikemukakan hasilhasil pengujian hipotesis baik untuk mengungkap perbedaan pengetahuan siswa tentang konsep dasar matematika ditinjau dari self-efficacy antara kelas yang diberi 
tes berupa strategi pembelajaran induktif dan strategi pembelajaran deduktif.

Uji statistik yang digunakan untuk menjawab hipotesis tersebut adalah Uji-t beda dua rataan. Sebelum melakukan uji statistik, terlebih dahulu dilakukan uji asumsi, yaitu uji normalitas data dengan menggunakan uji Kolmogorov-Smirnov dan uji homogenitas varians dengan menggunakan uji Levene. Hasil lengkap semua uji statistik menggunakan SPSS 21.

\section{Analisis Data Self-Efficacy (SE) Siswa} terhadap Kemampuan Pengetahuan Konsep Dasar Matematika

Data SE siswa diperoleh dari hasil pemberian angket dan dianalisis untuk mengetahui SE siswa. Sebelum dianalisis, data hasil angket dikonversi ke data

Tabel 5.1 Deskriptif Data SE Kelas Strategi Pembelajaran Induktif

\begin{tabular}{cccc}
\hline Interval & Kategori & $\boldsymbol{f}$ & \% \\
\hline $\mathrm{X} \geq 102.5686$ & Tinggi (T) & 20 & 17,24 \\
$\mathrm{X}<102.5686$ & Rendah (R) & 96 & 82,76 \\
Jumlah & & 116 & 100
\end{tabular}

Pada Tabel 4.1 dapat dilihat bahwa berdasarkan kategori SE untuk kelas dengan strategi pembelajaran induktif, yaitu kategori SE tinggi sebanyak 20 orang interval menggunakan MSI dengan aplikasi Succ97.xla. Kemudian data SE dibagi menjadi dua kategori, yaitu: SE tinggi, dan SE rendah. Keseluruhan hasil analisis data SE siswa terhadap Matematika dapat dilihat pada Lampiran.

a. SE Kelas dengan Strategi

Pembelajaran Induktif

Rangkuman hasil analisis deskriptif data SE siswa dengan strategi pembelajaran induktif, disajikan pada Tabel 5.1. 


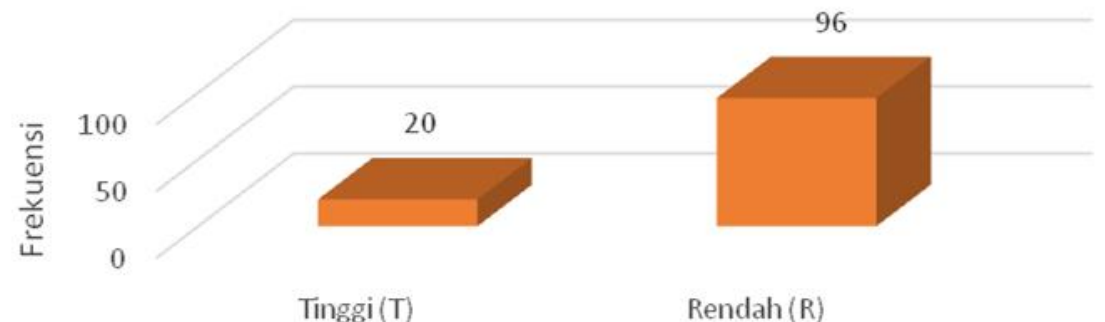

Kategori

Gambar 5.1 Kategori SE Siswa Kelas dengan Strategi Pembelajaran Induktif

b. SE Kelas dengan Strategi Strategi pembelajaran deduktif, disajikan pada Pemebelajaran Deduktif Tabel 5.2.

Rangkuman hasil analisis deskriptif

data SE siswa dengan strategi

Tabel 5.2 Deskriptif Data SE Kelas Strategi Pembelajaran Deduktif

\begin{tabular}{ccrr}
\hline Interval & Kategori & \multicolumn{1}{c}{$\boldsymbol{\%}$} \\
\hline $\mathrm{X} \geq 102.5686$ & Tinggi (T) & 23 & 18,55 \\
$\mathrm{X}<102.5686$ & Rendah (R) & 101 & 81,45 \\
Jumlah & & 124 & 100
\end{tabular}

Pada Tabel 5.2 dapat dilihat bahwa berdasarkan kategori SE untuk kelas dengan strategi pembelajaran deduktif, yaitu kategori SE tinggi sebanyak 23 orang atau $18.55 \%$, dan kategori SE rendah sebanyak 101 orang atau $81.45 \%$. Grafiknya sebagai berikut.

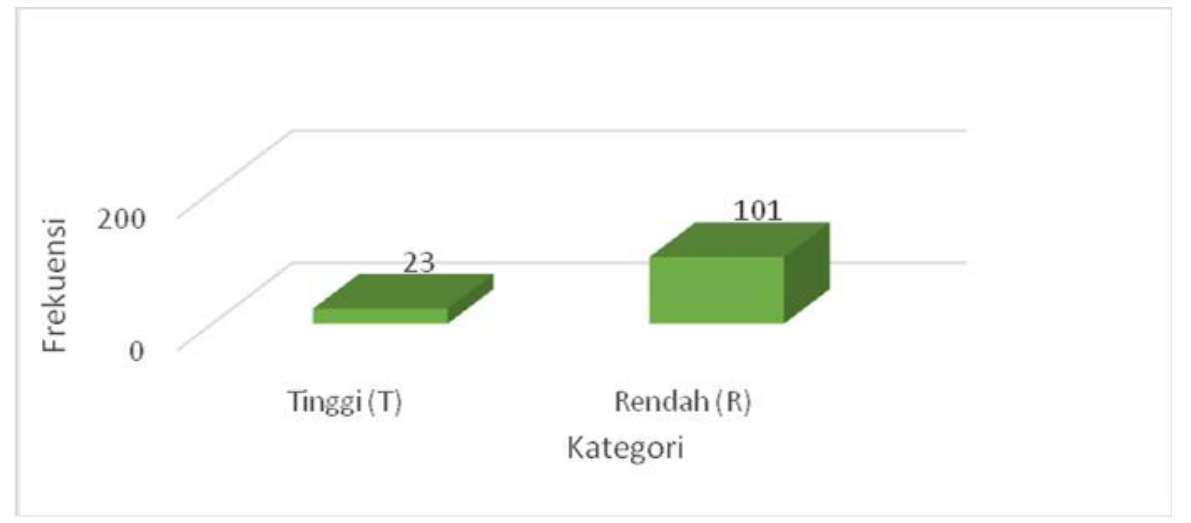

Gambar 5.2 Kategori SE Siswa Kelas dengan Strategi Pembelajaran Deduktif 
Analisis Deskriptif Hasil Tes Siswa

\section{dengan Strategi Pembelajaran Induktif}

a. Analisis Deskriptif Hasil Tes Siswa dengan Strategi Pembelajaran Induktif Analisis deskriptif data siswa merupakan deskripsi kemampuan pengetahuan dasar matematika siswa. Data skor tes sebelum dianalisis dikonversi

Tabel 5.3 Deskriptif Data Kelas dengan Strategi Pembelajaran Induktif

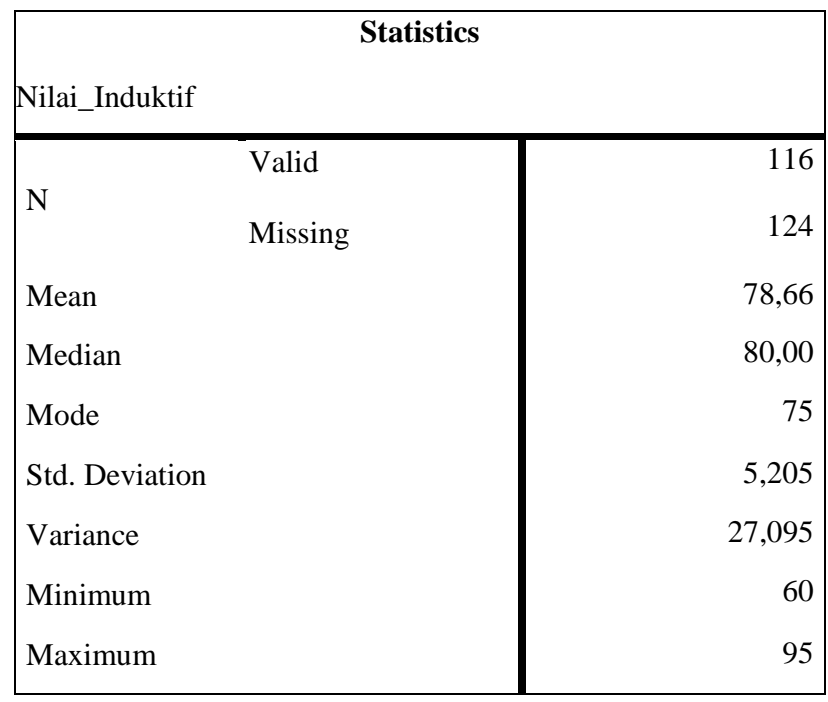

Dari hasil analisis menggunakan SPSS yang disajikan pada Tabel 5.3 diperoleh bahwa rataan tes dengan strategi pembelajaran induktif sebesar 78.66. Nilai tengah sebesar 80.00 dan nilai yang sering muncul diperoleh siswa sebesar 75. Nilai terlebih dahulu ke dalam skala 100 . Rangkuman hasil analisis deskriptif data siswa yang diberi tes dengan strategi pembelajaran induktif disajikan pada Tabel 5.3. 
Pada Tabel 5.4 dapat dilihat bahwa tes pembelajaran induktif berdasarkan kategori SE, yaitu tes pembelajaran induktif dengan SE tinggi diperoleh rataan tes sebesar 81,45 dengan standar deviasi sebesar 4,86 sedangkan tes pembelajaran induktif dengan SE rendah diperoleh rataan tes sebesar 78,08 dengan standar deviasi sebesar 5,1. Grafiknya sebagai berikut.

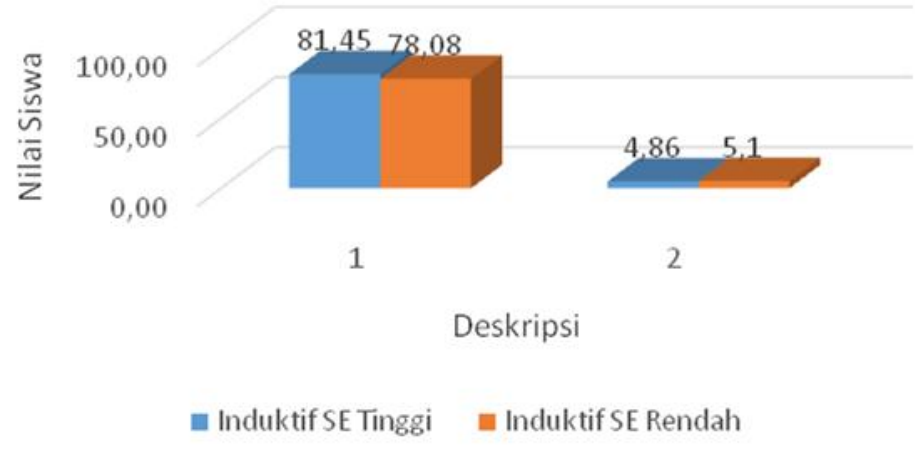

Gambar 5.3 Tes Strategi Pembelajaran Induktif dengan SE

\section{Analisis Deskriptif Hasil Tes Siswa} dengan Strategi Pembelajaran Deduktif

a. Analisis Deskriptif Hasil Tes Siswa dengan Strategi Pembelajaran Deduktif Analisis deskriptif data siswa merupakan deskripsi kemampuan pengetahuan dasar matematika siswa. Data skor tes sebelum dianalisis dikonversi terlebih dahulu ke dalam skala 100. Rangkuman hasil analisis deskriptif data siswa yang diberi tes dengan strategi pembelajaran induktif disajikan pada Tabel 5.5.

Tabel 5.5 Deskriptif Data Kelas dengan Strategi Pembelajaran Deduktif

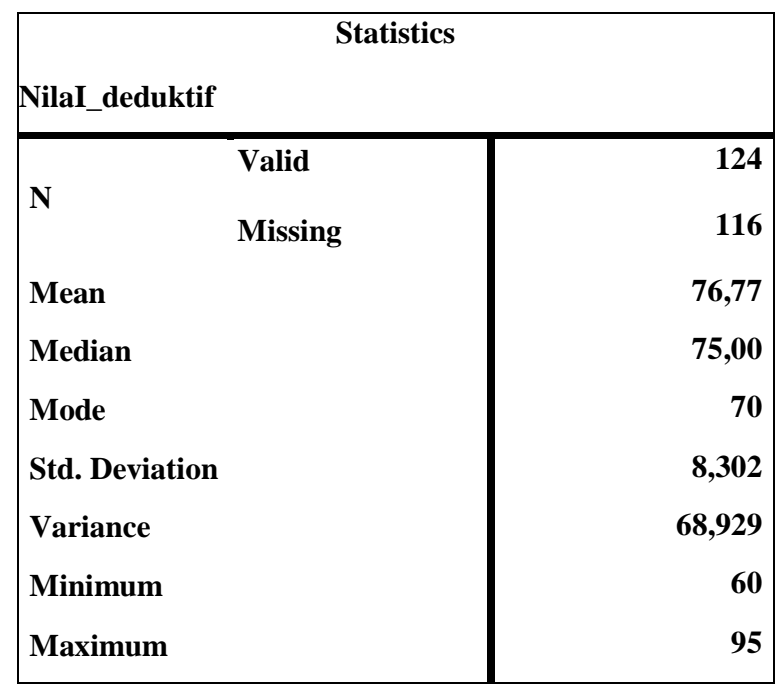


Dari hasil analisis menggunakan SPSS yang disajikan pada Tabel 5.5 diperoleh bahwa rataan tes dengan strategi pembelajaran deduktif sebesar 76.77. Nilai tengah sebesar 75.00 dan nilai yang sering muncul diperoleh siswa sebesar 70. Nilai paling rendah sebesar 60 dan nilai tertinggi sebesar 95.

b. Analisis Deskriptif Hasil Tes Strategi Pembelajaran Deduktif dengan SE

Rangkuman hasil analisis deskriptif tes strategi pembelajaran deduktif dengan SE siswa disajikan pada Tabel 5.6.

Tabel 5.6 Deskriptif Hasil Tes Strategi Pembelajaran Deduktif dan SE

\begin{tabular}{lcr}
$\begin{array}{l}\text { Tes Pembelajaran } \\
\text { Induktif }\end{array}$ & Rataan & $\begin{array}{r}\text { Standar } \\
\text { Deviasi }\end{array}$ \\
\hline Deduktif SE Tinggi & 77,65 & 6,92 \\
Deduktif SE Rendah & 76,56 & 8,6
\end{tabular}

Pada Tabel 5.6 dapat dilihat bahwa tes pembelajaran deduktif berdasarkan kategori SE, yaitu tes pembelajaran deduktif dengan SE tinggi diperoleh rataan tes sebesar 77,65 dengan standar deviasi sebesar 46,92 sedangkan tes pembelajaran deduktif dengan SE rendah diperoleh rataan tes sebesar 76,56 dengan standar deviasi sebesar 8,6. Grafiknya sebagai berikut.

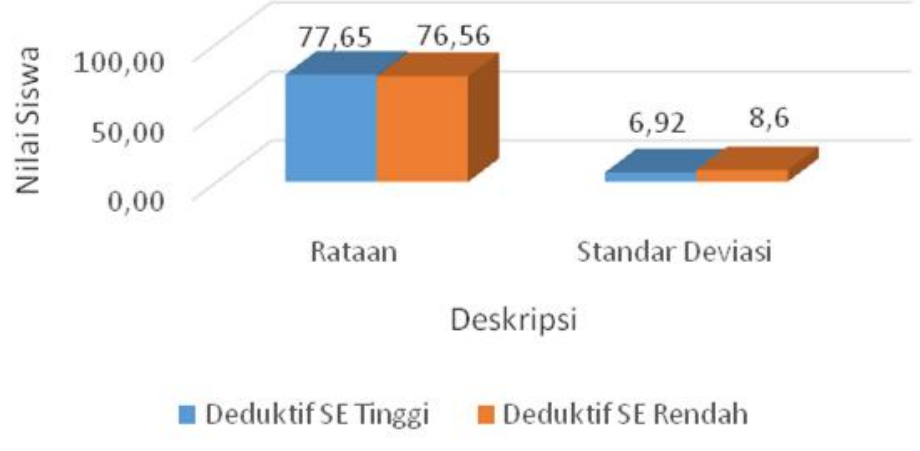

Gambar 5.4 Tes Strategi Pembelajaran Deduktif dengan SE

Analisis Deskriptif Perbandingan Hasil

Tes Siswa dengan Strategi

Pembelajaran Induktif dan Strategi Pembelajaran Deduktif

Berdasarkan Tabel 4.3 dan Tabel 4.5 diperoleh deskripsi perbandingan rata-rata dan standar deviasi kedua kelas, yaitu kelas yang diteskan dengan strategi pembelajaran induktif dan strategi pembelajaran deduktif seperti yang disajikan pada Gambar 4.5. 

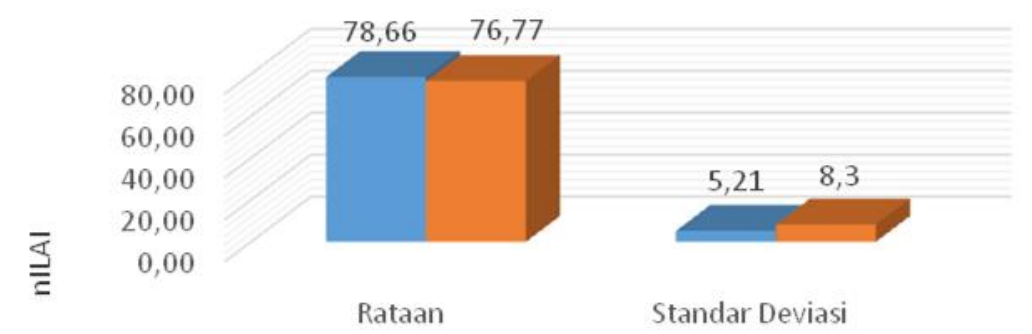

dESKRIPSI

m Induktif $=$ Deduktif

Gambar 5.5 Perbandingan Rataan dan Standar Deviasi Kelas Induktif dan Deduktif

Berinterpretasi pada Gambar 5.5 diperoleh bahwa pada kelas yang diteskan dengan strategi pembelajaran induktif nilai rataan sebesar 78.66 dengan standar deviasi 5.21, sedangkan nilai rataan yang diteskan dengan strategi pembelajaran deduktif nilai rataan sebesar 76.77 dengan standar deviasi 8.30 .

Berdasarkan Tabel 5.4 dan Tabel 5.6 diperoleh deskripsi perbandingan rata-rata dan standar deviasi kedua kelas dengan kategori SE, yaitu kelas strategi pembelajaran induktif dengan kategori SE tinggi dan SE rendah dan kelas strategi pembelajaran deduktif dengan kategori SE tinggi dan SE rendah seperti yang disajikan pada Gambar 5.6 dan Gambar 5.7 .

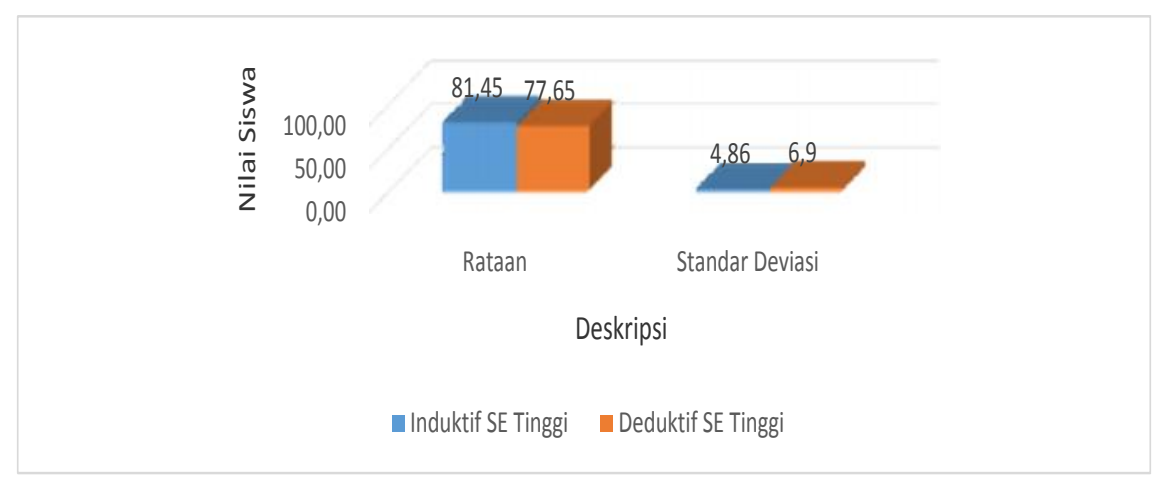

Gambar 5.6 Perbandingan Rataan dan Standar Deviasi Kelas Induktif dan Deduktif Dengan SE Tinggi

Berinterpretasi pada Gambar 5.6 diperoleh bahwa pada kelas strategi pembelajaran induktif dengan SE tinggi nilai rataan sebesar 81.45 dengan standar deviasi 4.86, sedangkan nilai rataan kelas strategi pembelajaran deduktif dengan SE tinggi nilai rataan sebesar 77.65 dengan standar deviasi 5,90. Adapuan perbandingan kelas pembelajaran Induktif dan pembelajaran deduktif dengan SE 
rendah dapat dilihat pada Gambar 5.7 dibawah ini:

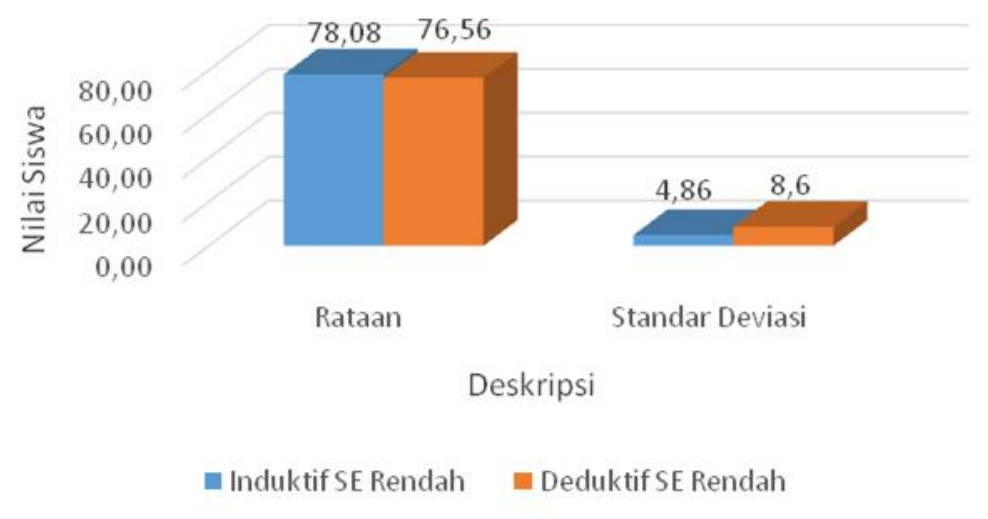

Gambar 5.7 Perbandingan Rataan dan Standar Deviasi Kelas Induktif dan Deduktif Dengan SE Rendah

Berinterpretasi pada Gambar 5.7 diperoleh bahwa pada kelas strategi pembelajaran induktif dengan SE rendah nilai rataan sebesar 78.08 dengan standar deviasi 4.86, sedangkan nilai rataan kelas strategi pembelajaran deduktif dengan SE rendah nilai rataan sebesar 76.56 dengan standar deviasi 8,60.

\section{Analisis Inferensial Kelas Pembelajaran} Induktif dan Kelas Pembelajaran Deduktif Ditinjau Dari Self Efficacy (SE) Terhadap Kemampuan

\section{Pengetahuan Konsep Dasar Matematika}

Analisis statistik inferensial yang dilakukan diawali dengan beberapa uji prasyarat, di antaranya uji normalitas dan uji homogenitas varians. Uji normalitas dilakukan untuk mengetahui apakah data berdistribusi normal atau tidak sedangkan uji homogenitas varians dilakukan untuk mengetahui homogen atau tidaknya varians dari populasi.

Pengujian hipotesis data dilakukan terhadap nilai siswa pada masing-masing rumusan hipotesis. Setelah dilakukan uji prasyarat, dilakukan pengujian hipotesis yaitu dengan statistik parametrik. Uji tersebut dilakukan dengan uji-t beda dua rataan menggunakan SPSS 21 dengan taraf signifikansi $\alpha=0.05$. Kriteria $\mathrm{H}_{0}$ ditolak jika nilai Sig. $<\alpha=0.05$ dan sebaliknya $\mathrm{H}_{0}$ diterima jika nilai Sig. $\geq \alpha=0.05$. Keseluruhan hasil analisis statistiknya menggunakan SPSS dapat dilihat pada penjelasan dibawah ini.

a. Uji pengaruh strategi pembelajaran induktif dan strategi pembelajaran deduktif terhadap perbedaan pengetahuan siswa tentang konsep dasar matematika.

Langkah awal yang dilakukan adalah uji prasyarat, yaitu uji normalitas dan uji 
homogenitas Pengujian normalitas data $\quad \mathrm{H}_{0} \quad$ : sampel berdistribusi normal dilakukan terhadap nilai pada $\mathrm{H}_{1} \quad$ : sampel tidak berdistribusi pembelajaran induktif dan nilai pada normal

pembelajaran deduktif. Uji tersebut dilakukan dengan uji Kolmogorov-Smirnov menggunakan SPSS dengan taraf signifikansi $\alpha=0.05$.

Rumusan hipotesis yang digunakan untuk uji normalitas data yaitu:

Tabel 5.7 Uji Normalitas Data Kelas Induktif dan Deduktif

One-Sample Kolmogorov-Smirnov Test

\begin{tabular}{|ll|r|r|}
\hline & & Nilai_Induktif & NilaI_deduktif \\
\hline $\mathrm{N}$ & & 116 & 124 \\
Normal Parameters & Mean & 78,66 & 76,77 \\
& Std. Deviation & 5,205 & 8,302 \\
& Absolute &, 156 &, 131 \\
Most Extreme Differences & Positive &, 156 &, 131 \\
& Negative &,- 144 &,- 103 \\
Kolmogorov-Smirnov Z & & 1,678 & 1,461 \\
Asymp. Sig. (2-tailed) & &, 067 &, 058 \\
\hline
\end{tabular}

Berdasarkan Tabel 5.6 diperoleh bahwa seluruh sampel kelas nilai $p$-value $\geq \alpha=$ 0.05, maka $\mathrm{H}_{0}$ diterima. Dengan diterimanya $\mathrm{H}_{0}$ maka dapat disimpulkan bahwa sebaran data berdistribusi normal.

Sebelum melakukan uji hipotesis terlabih dahulu dilakukan uji homogenitas. Uji homogenitas data dilakukan pada masing-masing rumusan hipotesis. Uji tersebut dilakukan dengan Levene Test menggunakan SPSS dengan taraf signifikansi $\alpha=0.05$.

Rumusan hipotesis yang digunakan untuk uji homogenitas data yaitu:

$\mathrm{H}_{0} \quad$ : data memiliki varians yang homogen
$\mathrm{H}_{1} \quad$ : data memiliki varians yang tidak homogen

Kriteria pengujian yang digunakan adalah: jika $p$-value (Sig.) $>\alpha=0.05$, maka $\mathrm{H}_{0}$ diterima; sebaliknya hal lainnya $\mathrm{H}_{0}$ ditolak. Hasil analisis dapat dilihat pada Tabel 4.7. Berdasarkan Tabel 4.7 pada kolom Levene Test diperoleh nilai Sig.= 0.000, sebab nilai Sig $<\alpha=0.05$, dapat dikatakan bahwa gabungan kedua strategi pembelajaran memiliki varians yang tidak homogen.

Langkah selanjutnya adalah uji hipotesis data terhadap kelas induktif dan deduktif dengan menggunakan Uji-t data tidak berpasangan. Rangkuman hasil uji hipotesis 1 disajikan pada Tabel 5.8. 
Tabel 5.8 Hasil Uji Hipotesis 1

Independent Samples Test

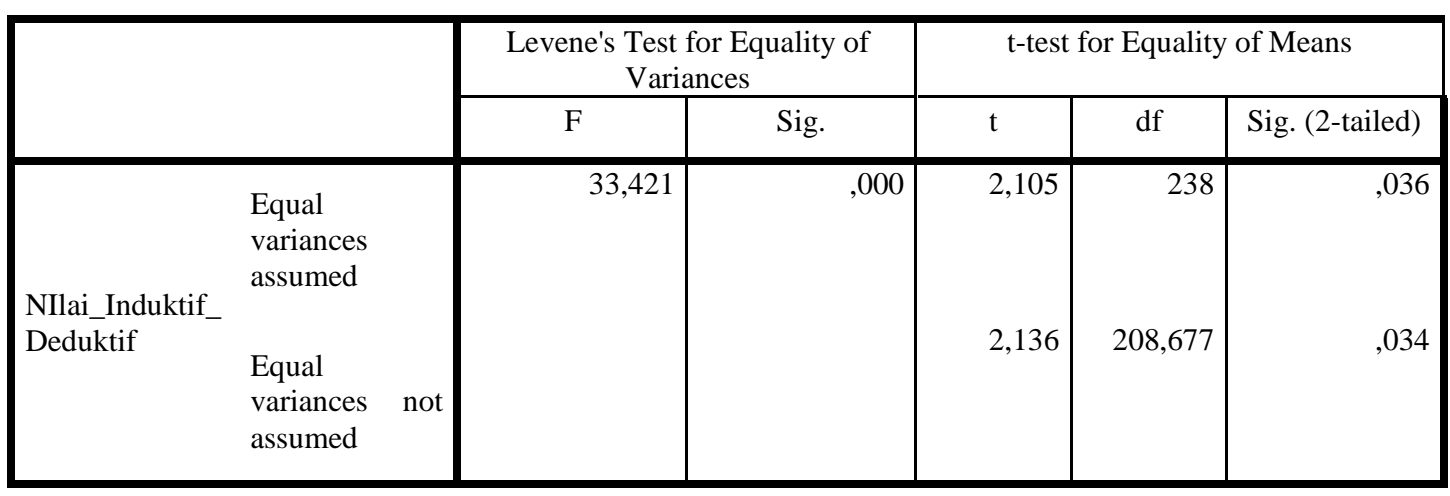

Berdasarkan Tabel 5.7 diperoleh bahwa Nilai $\mathrm{t}=2,136$ dengan Sig. $=0.034$, Karena nilai Sig. $<\alpha=0.05$, maka dapat disimpulkan bahwa secara signifikan ada pengaruh strategi pembelajaran induktif dan strategi pembelajaran deduktif terhadap perbedaan pengetahuan siswa tentang konsep dasar matematika.

b. Uji pengaruh interaksi strategi pembelajaran (A) dan self-efficacy (B) terhadap pengetahuan siswa tentang konsep dasar matematika

Pengujian hipotesis ini dilakukan dengan menggunakan ANAVA dengan Rancangan Acak Kelompok. Rangkuman hasil uji hipotesis 2 disajikan pada Tabel 5.9 .

Tabel 5.9 Hasil Uji Hipotesis 2

Tests of Between-Subjects Effects

Dependent Variable: Nilai_IN_DE

\begin{tabular}{|l|r|r|r|r|r|}
\hline Source & $\begin{array}{r}\text { Type III Sum of } \\
\text { Squares }\end{array}$ & df & Mean Square & F & Sig. \\
\hline Corrected Strategi & $379,965^{\mathrm{a}}$ & 2 & 189,983 & 3,939 &, 021 \\
Intercept & 866799,899 & 1 & 866799,899 & 17973,066 &, 000 \\
Kelas_IN_DE & 222,223 & 1 & 222,223 & 4,608 &, 033 \\
SE & 164,138 & 1 & 164,138 & 3,403 &, 046 \\
Error & 11429,968 & 237 & 48,228 & & \\
Total & 1460138,000 & 240 & & & \\
Corrected Total & 11809,933 & 239 & & & \\
\hline
\end{tabular}

Berdasarkan Tabel 5.9 diperoleh bahwa pada baris kelas nilai $F=4.608$ dengan Sig. $=0.033$. Karena nilai Sig. $<\alpha=0.05$, maka dapat disimpulkan bahwa secara signifikan ada pengaruh interaksi strategi pembelajaran (A) dan self-efficacy terhadap pengetahuan siswa tentang konsep dasar matematika.

c. Uji pengaruh strategi pembelajaran induktif dan strategi pembelajaran deduktif 
terhadap perbedaan pengetahuan siswa tentang konsep dasar matematika pada

\section{Pembahasan}

Hasil analisis data baik dari analisis deskriptif maupun analisis inferensial menunjukan bahwa ada pengaruh strategi pembelajaran induktif dan strategi pembelajaran deduktif terhadap perbedaan pengetahuan konsep dasar matematika siswa. Tetapi setelah membandingkan pada masing-masing strategi melalui uji statistik dan deskriptif, maka terdapat pengaruh yang signifikan pengetahuan konsep dasar matematika siswa antara kelompok siswa yang dites dengan menggunakan strategi pembelajaran induktif dan strategi pembelajaran deduktif. Hal ini terlihat pada nilai rataan kedua kelompok yang menyimpulkan bahwa nilai rata-rata siswa yang dites dengan strategi pembelajaran induktif lebih tinggi dari pada nilai rata-rata siswa yang dites dengan strategi pembelajaran deduktif. .

Strategi pembelajaran induktif dirancang untuk membantu siswa mengembangkan pengetahuan konsep dasar matematika siswa dan mengolah informasi serta membantu menyelesaikan masalah dalam hal ini adalah pengetahuan konsep dasar matematika siswa. Strategi pembelajaran induktif diawali dengan guru mengarahkan siswa secara aktif dalam situasi pembahasan materi pelajaran kelompok siswa yang memiliki self efficacy tinggi.

dengan memberi kesempatan pada siswa untuk mengungkapkan contoh-contoh atau hal-hal konkrit kemudian secara perlahanlahan dihadapkan pada materi kompleks dan sukar.Strategi induktif berupaya menyajikan materi secara umum ke husus, atau dimulai dari hal-hal yang abstrak menuju kehal-hal yang kongkrit.

Sedangkan strategi pembelajaran deduktif merupakan model pembelajaran melibatkan siswa mempelajari konsepkonsep terlebih dahulu yang disampaikan guru kemudian dicari kesimpulan dan ilustrasi-ilustrasi; atau bahan pelajaran dipelajari dimulai dari hal-hal abstrak, kemudian secara perlahan-lahan menuju hal yang konkrit.Dalam hal ini guru lebih aktif mempersiapkan materi pelajaran dan menyajikannya kepada siswa

Berdasarkan uraian di atas dapat disimpulkan bahwa strategi pembelajaran induktif lebih baik daripada strategi pembelajaran deduktif terhadap pengetahuan konsep dasar matematika siswa. Penerapan strategi pembelajaran induktif telah dapat meningkatkan pengetahuan konsep dasar matematika siswa ditinjau dari kategori SE tinggi. Dari kedua bentuk perlakuan tersebut, strategi pembelajaran induktif lebih berpengaruh dibandingkan dengan strategi pembelajaran deduktif terhadap 
pengetahuan konsep dasar matematika siswa.

\section{KESIMPULAN}

Berdasarkan hasil penelitian dan pembahasan, maka kesimpulan dalam penelitian ini adalah sebagai berikut:

1. Terdapat pengaruh strategi pembelajaran induktif dan strategi pembelajaran deduktif terhadap perbedaan pengetahuan siswa tentang konsep dasar matematika.

2. Terdapat pengaruh interaksi strategi pembelajaran (A) dan self-efficacy terhadap pengetahuan siswa tentang konsep dasar matematika.

3. Terdapat pengaruh strategi pembelajaran induktif dan strategi pembelajaran deduktif terhadap perbedaan pengetahuan siswa tentang konsep dasar matematika pada kelompok siswa yang memiliki self efficacy tinggi.

4. Tidak ada pengaruh strategi pembelajaran induktif dan strategi pembelajaran deduktif terhadap perbedaan pengetahuan siswa tentang konsep dasar matematika pada kelompok siswa yang memiliki self efficacy rendah.

\section{DAFTAR PUSTAKA}

Agung, I Gusti Ngurah.Applied Mathematics in Social Sciences, Jakarta: The Ary Suta Center,2008.
Aiken, Lewis R. Psychological Testing and Assessment, (Eight Edition), Boston: Allyn and Bacon.1994.

Anastasi.Anne and Urbina, Susana.Psicohological Testing.(Seventh Edition). New Jersey: Prentince-Hall,Inc.1997.

Anonymous.Undang-Undang RI Nomor 20 Tahun 2003 Tentang Sistem Pendidikan Nasional, Bandung: Fokusmedia,2003.

Arikunto,Suharsimi. Dasar-Dasar Evaluasi Pendidikan.Jakarta: PT Bumi Aksara,2003

Suharsimi. Prosedur Penelitian.Jakarta: Rineka Cipta,2002.

Azwar Saifuddin. Tes Pretasi. Bandung: Pustaka Pelajar,2002.

Saifuddin.Reliabilitas dan Validitas.Yogyakarta: Liberty, 1998.

Bell, Frederick H. Teaching and Learning Mathematics.1981

Bloom, Benyamin S.(Ed.) et al. Taxonomy of Educational Obyectives, Hanbook I Cognitive Domain. New York: David McKay,1976.

Brown, F.G. Principles of Educational and Psychological Testing. New York: Holt, Rinehart and Winston

Djaali, dan Puji Mulyono, Pengukuran Dalam Bidang Pendidikan. Jakarta: PPS UNJ.2004

Djaali, Made Putrawan, dan Sugilar, Pengembangan Strategi Pembelajaran Matematika Di Sekolah Dasar Sesuai Perkembangan Kesiapan Intelektual Anak. Jakarta: Lembaga Penelitian Universitas Negeri Jakarta.2001 